\title{
Isozymic and Mitotic Studies in Wheat-Rye Crosses for Confirmation of their Hybridity
}

\author{
P. N. Jagadev ${ }^{*}$ and V. K. Khanna ${ }^{2}$ \\ ${ }^{1}$ Department of Plant Breeding and Genetics, OUAT, Bhubaneswar, India \\ ${ }^{2}$ Department of Genetics and Plant Breeding, GBPUAT, Pantnagar, India \\ *Corresponding author
}

\section{A B S T R A C T}

\begin{tabular}{|l|}
\hline Key w or d s \\
Peroxidase, \\
Isozyme, Mitosis, \\
Wheat, Rye \\
\hline Article Info \\
$\begin{array}{l}\text { Accepted: } \\
\text { 07 January } 2021 \\
\text { Available Online: } \\
\text { 10 February } 2021\end{array}$ \\
\hline
\end{tabular}

The present investigation was undertaken to study the peroxidase isozymes and mitotisin wheat-rye crosses of four wheat and two rye genotypes to confirm their hybridity. The hybrids showed a combination of both the parental bands along with some new bands at various positions with different intensities. Some parental bands were also missing in all the hybrids. Cluster analysis using the data from peroxidase isozymes indicated that considerable genetic distances existed among the hybrids and their parents. Among the hybrids, maximum genetic distance was seen between Hope $\mathrm{x}$ Russian rye and Highbury $\mathrm{x}$ Russian rye. Among the parents, Hope was genetically most distant from Rye 8461 indicating that a successful hybrid could be got from them. Mitotic abnormalities of chromosomes in the hybrid root tips were also observed in the form of bridges at anaphase. The somatic chromosome numbers were 21 and 28 in most of the cases, but in one cell 35 chromosomes were seen.

\section{Introduction}

Realizing the importance of isozymes as genetic markers, they have been used to characterize cultivars in a variety of crop plants. Electrophoretic patterns of different enzymes have been studied to characterize cultivars of wheat and triticale as marker of ploidy level in crop plants (Asins et al., 1981) and to confirm evidence for hybridity in intergeneric hybrids (Fedak, 1977). In the present investigation, an attempt has been made to characterize some of the diverse genetic stocks of wheat and rye by studying the genetic distances among their hybrids and parents by confirming their hybridity through peroxidase isozymic patterns and mitotic studies.

\section{Materials and Methods}

The experimental material consisted of five genotypes of hexaploid wheat (Triticum aestivum L.), viz. Chinese Spring (CS), Hope, Highbury, CS/Hope 5B (a substitution line)and UP 2338, a genotype of tetraploid wheat (WH 896) and two genotypes of diploid rye (Secale cereale L.) viz. Rye 8461 and Russian rye. Emasculation was done during the morning and evening hours on 
randomly selected plants when anthers were still pale green and two days later, when the stigmas were feathery and receptive, the pollinations were performed by hand pollinating the pistils with dusting of pollens from dehiscing anthers of the male parents. The hybrid seeds set were collected at maturity and grown in a glass house along with the parents.

To study the peroxidase isozyme, the leaves of 20 days old seedlings of wheat, rye and their hybrids were homogenized ina prechilled mortar and pestle with 3-5 $\mathrm{ml}$ of icecold 0.9 per cent $\mathrm{NaCl}$ solution. The homogenate was stored at $4^{\circ} \mathrm{C}$ for $6-12$ hours and then centrifuged. The clear supernatant was carefully decanted and the pellet containing cell debris was discarded. The supernatant was filled separately in dialysis bags and dialysed against 60 per cent sucrose solution at $4^{\circ} \mathrm{C}$ for about 3 hours. Then, for polyacrylamide gel electrophoresis, the method of Laemmli (1970) was followed. Peroxidase isozyme banding pattern was studied as per the method suggested by Liu (1971). The genetic distance between two samples was calculated following Chen et al., (1997) and the data were subjected to cluster analysis using unweighted pair-group method for arithmetic averages (UPGMA) analysis following Sneath and Sokal (1973). To make slides for mitotic studies, the root tips were squashed in 2 per cent acetocarmine stain after hydrolyzing in $1 \mathrm{~N} \mathrm{HCl}$ for 5-10 minutes. The data on various chromosomal abnormalities, such as laggards and bridges at metaphase and anaphase stages were recorded. The mitotic index was calculated as the ratio of number of dividing cells to total number of cells observed.

\section{Results and Discussion}

In the present investigation, peroxidase has been used as a genetic marker to study the expression of genome. Differences in gene expression in different plants were reflected in their isozyme patterns. Depending upon their electrophoretic mobility, the observed isozymes of peroxidase were divided into four groups and the bands in these groups were represented by subscripts $a, b, c, \ldots \ldots, 1$ in increasing order of the electrophoretic mobilities within the group. A total of 7,9 , 10, 12, 8 and 8 bands were observed in Hope, Highbury, CS/Hope 5B, UP 2338, Russian rye and Rye 8461, respectively (Fig. 1).

In Hope, two bands were seen in group 1, three in group 2, none in group 3 and two in group 4. In Highbury, three bands each in group 1 and group 2, one in group 3 and two in group 4 were noticed. In CS/Hope 5B, 5 bands were observed in group1, three in group 2, one each in group 3 and group 4 . In UP 2338, group 1 had four bands, group 2 had two, group 3 had four and group 4 had two bands. The rye varieties, viz. Russian rye and Rye 8461 had eight bands each. In group 1, both varieties had three bands each. Group 2 consisted of two bands in Russian rye and three bands in Rye 8461. In group 3, Russian rye had one band and no band was seen in Rye 8461 . In group 4, both the rye varieties had two bands each.

In Hope-Russian rye cross (Fig. 1) only one Hope specific band (1j) and one Russian rye specific band (4c) were seen. Bands $2 b$ and $2 g$ were shared by both the parents. Some new bands like $1 \mathrm{~b}, 1 \mathrm{e}, 3 \mathrm{a}$ and $3 \mathrm{~g}$ were seen in the hybrids which were absent in the parents. In the case of Highbury-Russian rye cross, five bands were Highbury specific and two bands (1d and 3i) were Russian rye specific. Two bands ( $1 \mathrm{k}$ and $2 \mathrm{~b}$ ) were common to both the parents. A new band (1a) also appeared in the hybrid.In CS/Hope 5B-Rye 8461 cross, five bands were CS/Hope 5B specific and one (2c) was Rye 8461 specific. Two bands (1h and 2d) were common to both the parents. Some 
new bands like $2 \mathrm{~g}, 3 \mathrm{~b}$ and $4 \mathrm{f}$ were also observed in the hybrid. In UP 2338-Rye 8461 cross, three female parental bands ( $3 \mathrm{~b}, 3 \mathrm{f}$ and $3 \mathrm{~h}$ ) and one male parental band (4e) were observed. Five bands (1c, 1h, 1k, 2b and 4b) were common to both the parents. A new band (4h) also appeared in the hybrid. Hence, the results showed that more number of female parental bands were present in the hybrids (Fig. 1).

Cluster analysis revealed that the parents and hybrids could be divided into two groups at the genetic distance 0.76 and into three groups at 0.74 (Fig. 2). Considerable genetic distances existed among the hybrids and their parents. Among the hybrids, maximum genetic distance (0.89) was seen between Hope x Russian rye and Highbury x Russian rye. Among the parents, Hope was genetically most distant from Rye 8461 (0.87) followed by the genetic distance between UP 2338 and Russian rye (0.80), while Highbury was equidistant from both the rye genotypes (0.77). Hence, a successful hybrid could be obtained from the cross of Hope $x$ Rye 8461 followed by UP 2338 x Russian rye.

Table.1 Mitotic index and cytological abnormalities (bridges) at anaphase during mitosis in different wheat-rye crosses

\begin{tabular}{|l|c|c|c|c|}
\hline \multicolumn{1}{|c|}{ Cross } & $\begin{array}{c}\text { No. of } \\
\text { cells } \\
\text { observed }\end{array}$ & $\begin{array}{c}\text { No. of } \\
\text { dividing } \\
\text { cells }\end{array}$ & $\begin{array}{c}\text { Mitotic } \\
\text { index }\end{array}$ & $\begin{array}{c}\text { No. of cells } \\
\text { with bridges } \\
(\%)\end{array}$ \\
\hline CS x Rye 8461 & 102 & 12 & 11.76 & $2(1.96)$ \\
\hline CS x Russian rye & 92 & 10 & 10.87 & $\mathbf{2 ( 2 . 1 7 )}$ \\
\hline CS/Hope 5B x Rye 8461 & 122 & 11 & 9.02 & $\mathbf{6 ( 4 . 9 2 )}$ \\
\hline CS/Hope 5B x Russian rye & 105 & 9 & 8.57 & $4(3.81)$ \\
\hline UP 2338 x Rye 8461 & 115 & 9 & 7.83 & $\mathbf{5 ( 4 . 3 5 )}$ \\
\hline WH 896 x Rye 8461 & 118 & 13 & 11.02 & $\mathbf{3 ( 2 . 5 4 )}$ \\
\hline
\end{tabular}

Fig.1 Zymogram showing the electrophoretic pattern of leaf peroxidase in wheat, rye and their hybrids $(\mathrm{HP}=\mathrm{Hope}$; HB = Highbury, CS/HP = Chinese Spring/Hope 5B; UP= UP 2338; RR = Russian Rye; R8 = Rye 8461)

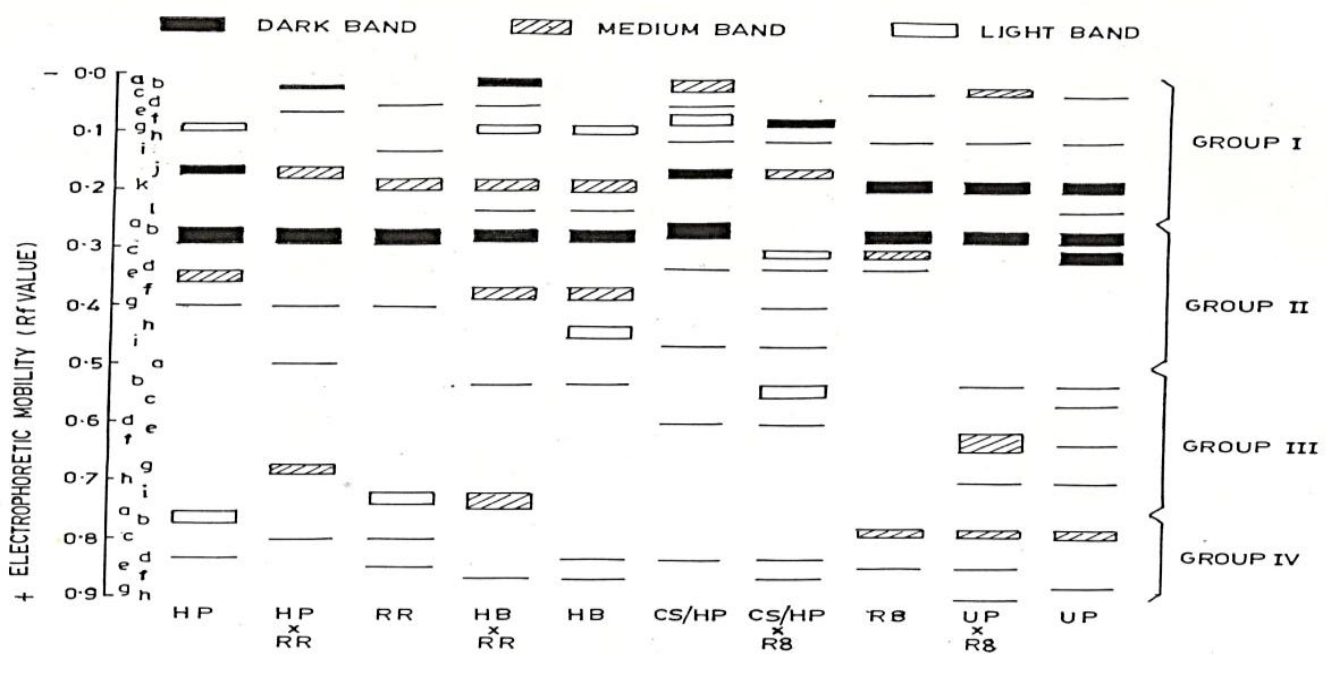


Fig.2 Dendrogram of wheat, rye and their hybrids based on isozyme analysis $(\mathrm{HP}=\mathrm{Hope}$; $\mathrm{HB}=$ Highbury, CS/HP = Chinese Spring/Hope 5B; UP= UP 2338; RR = Russian Rye; R8 = Rye 8461)

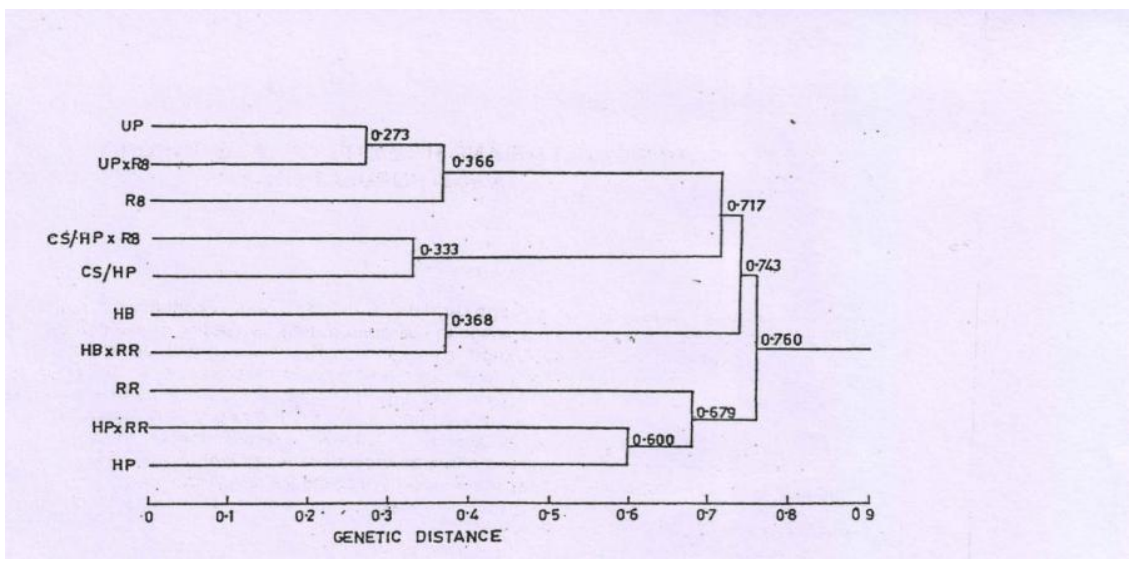

Fig.3 Mitotic cell division studies (A) CS x Rye 8461 showing normal metaphase (1000 X), (B) CS/Hope 5B x Russian rye showing normal anaphase (1000 X); (C) UP 2338 x Rye 8461 showing bridge at anaphase $(1000 \mathrm{X})$

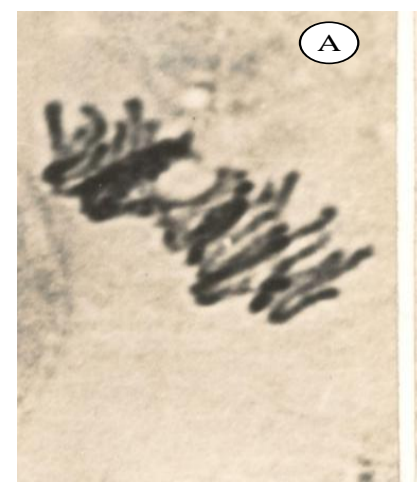

\section{Mitosis of parents and hybrids}

Mitotic studies showed that the wheat parents had 42 chromosomes and rye had 14. Chromosome number variation was observed in the root tip cells of the plantlets of the hybrids. Some plantlets had 28 chromosome as expected, comprising 21 of wheat and 7 of rye. Others had 21 chromosomes, which were assumed to be haploids of wheat. One plantlet had 35 chromosomes, which could be the result of an unreduced pollen with 14 chromosomes from rye fertilizing the egg of wheat having 21 chromosomes. Many cells in the hybrids showed bridges (Fig. 3). The mitotic index was highest (11.76) in CS x Rye 8461 (Table 1). Nuclear instability in triticale (wheat-rye cross) endosperm often began with the formation of a chromatin bridge at anaphase (Bennett, 1974).The replication of rye genome takes longer time to complete $S$ phase than wheat. Then under certain circumstances, rye chromosome may enter mitosis having failed to complete replication at one or both telomeres, which resulted in bridge formation at anaphase (Khanna et al., 1994).Hence, the isozymic followed by mitotic studies confirmed the hybridity of the plantlets obtained in wheat-rye crosses. 


\section{References}

Asins, M.J., Benito, C. and Perezdela Vega, M. 1981. Endosperm peroxidase electrophoresis Pattern to distinguish tetraploid from hexaploid wheats. Euphytica. 30: 389-392.

Bennett, M.D. 1974. Meiotic, gametophytic and early endosperm development in triticale. In: Triticale (eds. Macintyre, M. and Campbell, M.), IDRC, Canada. Pp. 137-148.

Chen, J., Isshiki, S., Tashiro, Y. and Miyazaki, S. 1997. Biochemical affinities between Cucumis hystris Chakr. and two cultivated Cucumis species (C. sativus $\mathrm{L}$. and $C$. melo $\mathrm{L}$.) based on isozyme analysis. Euphytica. 97: 139-141.

Fedak, G. 1977. Increased homeologous chromosome pairing in Hordeum vulgare $\mathrm{x}$ Triticum aestivum hybrids. Nature. 266: 429-430.

Khanna, V.K., Dhaubhadel, S., Kodali, S. and Garg, G.K. 1994. . Effect of hormones on wheat-barley crosses, embryo rescue and mitotic and isozymic studies in hybrids. Curr. Sci 67: 1003-1012.

Laemmli, V.K. 1970. Cleavage of structural proteins during the assembly of the head of bacteriophage $\mathrm{T}_{4}$. Nature, 227: 680685.

Liu, E. M. 1971. The isozymic forms of peroxidase found in the horse radish plant. In: Plant Cell, Tissue and Organ Culture (eds. Reinert, J. and Bajaj, Y.P. S.), Springer, New York, pp.719-730.

Sneath, P. H. A. and Sokal, R. R. 1973. Taxonomic structure. In: Numerical Taxonomy. W. H. Freeman \& Co., San Francisco. pp. 188-308.

\section{How to cite this article:}

Jagadev, P. N. and Khanna, V. K. 2021. Isozymic and Mitotic Studies in Wheat-Rye Crosses for Confirmation of their Hybridity. Int.J.Curr.Microbiol.App.Sci. 10(02): 528-532. doi: https://doi.org/10.20546/ijcmas.2021.1002.062 